\title{
ALGUNS CONTOS
}

\section{LUIS NASCIMENTO*}

\section{NOITE}

Caleidoscópio! Tudo segue na mais perfeita felicidade, caminho. Minhas botas, propositalmente gastas e desbotadas, continuam em passos ritmados: qual delas segue a outra? Vou indo! Paro na frente da velha casa, há quem diz que se pode ver na sacada o velho espectro contemplando o vôo de outrora. Tento, mas não o vejo. Escarro, jogo o cigarro na sarjeta, não o abandono antes de me certificar de que está completamente apagado. Alguém diz do outro lado da rua: "Não, não pode ser verdade!" Seria verdade?

As luzes se embaralham e até posso jurar que estão vivas. $\mathrm{O}$ motor do ônibus que passa me lembra um sax, as máquinas da fábrica ao lado parecem baterias. Sigo nesse jazz. Atravesso a grande avenida, estou na frente da telefônica. Lembro de ligar para alguém... esqueço. Volto para o lado esquerdo da avenida. Chuto uma folha de jornal deixada na calçada, ela sai voando. Admiro seu vôo e penso em decolar.

De longe o barulho dos bares, risos que se confundem com o apito do guarda. O gosto da cerveja sobe seco na garganta... vontade. Os cachorros conversam, os gatos rolam nos telhados. Um balão explode fogos, metralhadoras de artifício. Um gordo ri de seu próprio peso e larga a balança. No ponto de táxi, todos estão livres.

Quero ir para a estação, há muito que não olho os trens. No caminho vejo o vento brincar no playground. $O$ céu é a pobreza fardada de um soldado. Eles passam mais rápido do que o comum e seu prateado confunde-se com os trilhos. É como se trilho e trem fossem inseparáveis, um sendo a extensão do outro. Algumas pombas de estação ainda se assustam com o barulho cortante dos trilhos e voam. Lembro-me da folha de jornal e tento achar minha própria linha.

Luís Nascimento é graduando no Departamento de Filosofia, FFLCH-USP. 


\section{LUCAS}

Um barulho estridente veio atrapalhar o sono, Lucas abriu os olhos mas era como se ainda dormisse. Pensou ter visto o pai atravessar o corredor em direção à sala, seria tudo isso real? Era um sono de um olho só; vigília e devaneio ao mesmo tempo. O pai parecia falar com alguém na sala escura. Ouviu novos passos que iam em direção à sala, seria a mãe? "O que aconteceu?", sim era a mãe que se perguntava pela conversa que o pai tinha na sala

Só teve certeza de sua situação, e só pôde se por nela, quando acenderam a luz de seu quarto. Lá estavam o pai e a mãe, seus olhos ainda ofuscados não compreendiam aquela cena. Que horas seriam? Madrugada, muito escuro.

- Acorda Lucas, precisamos conversar.

A voz do pai. O cobertor pesava e livrar-se dele demorou alguns segundos. Sentou-se na cama.

- O vovô morreu.

A mãe em silêncio o olhava com extremo carinho, ternura demasiada - duvidou.

- Pelo que disseram o corpo está chegando ao velório. Quero saber se você quer ir comigo? Você não é obrigado, velório, aniversário, tudo isso é mera convenção. Apenas costumes, se morreu, morreu.

— Calma! era a mãe. Ele é só uma criança.

- Eu era apenas uma criança quando meu pai deu a notícia da morte do pai dele. Somos assim! A morte é só a morte, vive-se e morre. Não há razão para maiores distúrbios, meu pai morreu porque viveu e é só.

O pai fez uma pequena pausa, bocejou e olhou para Lucas.

- E então, você vai? É uma escolha sua, não há nada de errado em não ir.

- Então, por que você vai?

- Porque esse mundo é cheio dessas coisas, tenho que ir. Você é pequeno e ainda não precisa entrar no jogo. 
Lucas pensava enquanto olhava as formas geométricas estampadas em seu pijama. Sentia alguma coisa, o que era? Não podia definir, entretanto já havia sentido algo que se aproximava disso. Foi no primeiro dia de aula. Estavam atrasados, o pai levava-o pela mão, pararam na secretaria da escola, perguntaram pela sala da primeira série, nem bem a senhora gorda da secretaria respondeu e lá estavam os dois, de novo, entregues aos corredores do prédio antigo. A porta da sala oito estava fechada, o pai bateu. Uma jovem magra de olhos claros veio atender.

— Esse é o meu filho...

Terminadas as devidas apresentações, o pai o deixou. A moça magra indicou-lhe uma carteira vazia e lá foi se sentar sobre o olhar atento das outras crianças. Sentiu-se só no meio daquela gente estranha, era como se fosse o único o homem do mundo, como se não existisse mais ninguém; nem pai, nem mãe.

- E então Lucas?

O pai veio acordá-lo pela segunda vez. Lucas não disse nada, olhou para baixo e lentamente foi pondo os pés no chão. Frio, muito frio! Imediatamente os recolheu.

- Bom, eu preciso tomar um banho, você pensa no que quer fazer enquanto me lavo.

Dito isso o homem trancou-se no banheiro, despiu-se, parou alguns instantes na frente do espelho. Finalmente ligou o chuveiro e esperou que a água quente viesse lhe molhar para liberar poucas lágrimas camufladas.

\section{IO-IÔ}

Ela não perde cinco segundos ao vento, tudo o que passa por sua cabeça é endereçado. Hoje, curiosamente, estava extremamente carinhosa e escutou, por horas, as besteiras que explodiam de minha boca. Apresentou como sendo novos um par preto de sapatos. A luz do sol refletida no verniz do sapato deixava tudo muito claro. Era um clima calmo que nos dava o direito de mostrar os dentes - quase sem receio. Mas em algum lugar a tensão se escondia, camuflada pelo fim da tarde ela nos era imperceptível, mas sabíamos. 
Amanhã nos falaríamos, nem sequer um olhar. Sempre seria assim, desde que éramos crianças. E era a falta daquilo que não está mais conosco, mas está em nós. Fui para casa ver TV 